УДК 355.233 (477) (2014 - 2020)

ПОЛТАВЕЦЬ Ю. С.

https://orcid.org/0000-0001-9188-7468

https://doi.org/10.33577/2313-5603.34.2020.213-223

\title{
ДОСВІД ПІДГОТОВКИ ОФІЦЕРІВ У НАЦІОНАЛЬНІЙ АКАДЕМІЇ СУХОПУТНИХ ВІЙСЬК ІМЕНІ ГЕТЬМАНА ПЕТРА САГАЙДАЧНОГО В УМОВАХ ВІЙНИ НА СХОДІ УКРАЇНИ
}

Вивчається досвід підготовки офіцерів у Національній академії сухопутних військ імені гетьмана Петра Сагайдачного (НАCВ) під час агресії Російської Федерації проти України (2014 - 2020). Відзначається, що 2014 рік став для Українського війська найскладнішим, але саме тоді був запущений механізм докорінних змін щодо його реформування та зміцнення. Аналізується досвід підготовки курсантів ВВНЗ в роки проведення АТО та ООС.

Ключові слова: Національна академія сухопутних військ імені гетьмана Петра Сагайдачного, ЗС України, АТО, ООС, курсант.

Постановка проблеми. Збройний напад Російської Федерації (РФ) на Україну, анексія Криму та розв'язання війни на Сході Української держави навесні 2014 р. стали важким випробуванням бойової готовності для Збройних Сил України (ЗС України). Війна триває й дотепер, однак вже сьогодні можна констатувати, що керівництву Кремля не вдалося досягнути реалізації проєкту «Новоросія», зокрема загарбати південні і східні області України. Збройні сили України за короткий час відновили та наростили свій потенціал й зупинили агресора. Це, зокрема, стало можливим завдяки масовій громадянській підтримці, у тому числі у формі створення i відправки на фронт добровольчих військових формувань («добробатів»), виникненню й розгортанню масового волонтерського руху допомоги ЗС України серед населення країни, перебудові й реформуванню Української армії.

У відповідь на збройну агресію РФ та підтримку нею незаконних збройних формувань на Донбасі, що мали ознаки терористичної діяльності, Указом Президента України від 14 квітня 2014 року № 405/2014 було введено в дію рішення Ради національної безпеки та оборони України «Про невідкладні заходи щодо подолання терористичної загрози і збереження

Полтавець Юрій Сергійович, ад’юнкт науково-організаційного відділу, Національна академія сухопутних військ імені гетьмана Петра Сагайдачного, м. Львів.

С Полтавець Ю.С., 2020 
територіальної цілісності України». Згідно з цим рішенням в окремих районах Донецької та Луганської областей було розпочато широкомасштабну антитерористичну операцію (далі - ATO) iз залученням 3С України, Національної гвардії України та Служби безпеки України (Про рішення Ради нащіональної безпеки та оборони Украӥни..., 2014).

За час проведення АТО вдалося зупинити поширення війни на всю територію суверенної України та здійснити локалізацію зони збройного протистояння; вжити заходів щодо підвищення бойових спроможностей 3С, інших військових формувань, розвідувальних та правоохоронних органів; посилити обороноздатність держави; забезпечити підготовку іiі території, економіки та населення до оборони тощо. У 2014 р. під контроль української влади було повернуто понад 200 населених пунктів Донецької та Луганської областей, сформовано 29 нових бойових бригад і полків, створено окремі роди військ: Десантно-штурмові війська та Сили спеціальних операцій, реформовано систему Територіальної оборони, створено оперативний резерв, до якого зараховано більше 198 тис. резервістів, які мають досвід виконання завдань у зоні бойових дій (Євсєєв, 2019: 6-7). Воєнні дії затяглись. 30 квітня 2018 р. оголошено про завершення АТО й перехід до якісно нового етапу операції Об'єднаних сил (ООС). Суттєвий внесок у підвищення обороноздатності нашої держави вносять вищі військові заклади 3С України, зокрема Національна академія сухопутних військ імені гетьмана Петра Сагайдачного (далі - НАСВ).

Метою статті є висвітлення історичного досвіду реформування діяльності НАСВ під час проведення АТО та ООС, відображення внеску Академії у підготовку кадрових офіцерів для ЗС України.

Виклад основного матеріалу. НАСВ оперативно відреагувала на нові виклики і вимоги щодо підготовки українських офіцерів в умовах російсько-української війни. Вступна кампанія 2014 р. першого року війни, відрізнялася від попередніх тим, що державне замовлення на військових фахівців зросло удвічі. Серед нового набору курсантів з'явилися й учасники АТО. Наступного 2015 р. збільшився план набору. Академія прийняла тоді на перший курс 800 курсантів (Ткачук, Красюк та інші, 2015: 100.)

Певних змін зазнав і сам підхід до вишколу майбутніх офіцерів. Зміст навчання оперативно був наповнений досвідом, 
отриманим як підрозділами, так і командирами в ході проведення АТО. Забезпечувалася комплексність навчання організацією спільних групових вправ, збільшилися практичні польові заняття 3 навчальними групами різних спеціальностей. Відбувалися практичні комплексні польові заняття, які сприяли відпрацюванню курсантами тактичних прикладів застосування підрозділів у бойових діях на Сході України. Навчальні групи почали комплектуватися таким чином, що вони забезпечували проведення занять для двосторонньої зустрічної військової гри.

На Вченій раді Академії після початку агресії РФ постановили: для узагальнення досвіду АТО, який позитивно позначається на вишколі майбутніх офіцерів, а в подальшому 3 не меншим позитивом впливатиме на їхню якісну та швидку адаптацію до сучасних реалій військових підрозділів, потрібна обов'язкова присутність викладацького складу офіцерів-командирів як видового вишу, так і підрозділів НАСВ - Міжнародного центру миротворчості та безпеки (МЦМБ), 184 Навчального центру безпосередньо у зоні збройного протистояння.

Начальник НАСВ генерал-лейтенант П.П. Ткачук згадує: «3 початком збройного протистояння на Сході України ми відразу розпочали переводити виш, так би мовити, на «воєнні рейки». Ми добре усвідомлювали, що мусимо оперативно вносити корективи в навчальні програми 3 урахуванням досвіду АТО. Я вдячний підлеглим за розуміння моїх вимог щодо трансформації навчального процесу в умовах війни...Ми відмовилися від викладачів, які мали недостатні морально-ділові якості, які не змогли адаптуватися до динамічних процесів трансформації підготовки військових фахівців. Відтак дали «зелене світло» бойовим офіцерам, які брали участь в АТО, пройшли горнило афганської війни чи служили в миротворчих місіях у «гарячих» регіонах світу. Аналізуючи на початку Антитерористичної операції дії командирів підрозділів, ми констатували, що вони не завжди приймали вірні рішення на виконання бойового завдання. На це зреагували відповідні структури оборонного відомства, Генерального штабу 3С України, і до всіх вищих військових навчальних закладів надійшли матеріали з аналізом застосування військових частин та підрозділів під час АТО, конкретними рекомендаціями щодо використання в навчальному процесі набутого бойового досвіду» (Інтерв'ю $з$ генерал-лейтенантом П.П. Ткачуком: «Уроки війни:..., 2015). 
Навчально-викладацький склад, працівники Наукового центру, ад'юнкти займали посади у штабах керівництва секторів та безпосередньо керівників підрозділів, які були залучені для протидії агресору. На польовій базі Академії - Яворівському полігоні, регулярно відбувався вишкіл мобілізованих військовослужбовців, які готувалися до ротації в зону проведення бойових дій. На базі МЦМБ були створені осередки підготовки військовослужбовців - «блокпост», «базовий табір», «інженерне містечко», «житловий квартал».

В органах управління на передовій щодо планування вогневого ураження противника перебували офіцери-артилеристи та ракетники. Після ротації вони узагальнювали отриманий в зоні боїв матеріал, готували конкретні пропозиції щодо використання бойового досвіду в процесі навчання курсантів.

Не менш ефективною була діяльність офіцерів низової ланки. Вони відряджалися на посади командирів взводів, рот і батарей та безпосередньо керували підлеглими під час збройного протистояння. Ці воїни неодноразово за відмінну службу заохочувалися керівництвом АТО та ООС.

Представники вишу, 184 Навчального центру виконували також завдання щодо евакуації пошкоджених озброєнь та військової техніки. Спеціалісти Академії ремонтували техніку під вогнем противника. Офіцери 184 Навчального центру, викладачі та курсанти вишу долучалися також до зведення інженерних споруд у зоні протистояння. Для курсантів це була своєрідна практика щодо обладнання смуги оборони. Десятки разів науковопедагогічні та наукові працівники Академії відбували в зону боїв, на полігони, що розташовані поряд із зоною боїв, для навчання офіцерів та солдатів щодо застосування протитанкових ракетних комплексів.

Фахівці Наукового центру Сухопутних військ НАСВ, на замовлення Наукового управління Генштабу ЗС України провели дослідження існуючої системи діяльності органів державного управління, місцевого самоврядування, установ та організацій оборонного відомства, інших військових формувань і правоохоронних органів щодо їхнього функціонування в умовах дестабілізації суспільно-політичної обстановки з питань оборонної та мобілізаційної роботи. Даний аналіз був врахований при внесенні змін до існуючої законодавчої бази та інших нормативно-правових документів України. 
Наукові працівники Академії долучилися до натурних випробувань самохідної дистанційно керованої гусеничної машини, виготовленої ТОВ «Мейл Сервіс», безпілотного літального апарата, який планується використовувати для корегування артилерійського вогню батареєю 2 А36 та передачі розвідувальної інформації по локальній радіомережі Wi-Fi, а також автоматизованого комплексу розвідки «Базальт-ЛПР» (Ткачук, Красюк та інші, 2015: 101).

Науковий центр НАСВ розробив власну систему збору, вивчення та узагальнення бойового досвіду. 3 цією метою в район проведення АТО регулярно відряджалися дослідницькі групи, які працювали безпосередньо у військових підрозділах.

Зазнала змін підготовка офіцерів первинної ланки. Нинішнього командира механізованого взводу в Академії готують, виходячи 3 того, щоб він досконало оволодів порядком ведення бойових дій. Був і гранатометником, і снайпером, і кулеметником, і стрільцем, і командиром відділення тощо.

У тактичній підготовці офіцерів враховується досвід сучасної війни на Сході України. Так, на основі аналізу та виконання основних завдань, які стоять перед підрозділами під час проведення АТО-ООС, курсанти детально вивчають тактику дій «двійок», «трійок», підрозділу у складі бойових груп. Значна увага приділяється тренуванню солдата на полі бою. Для цього використовуються операційно-методичні карти та анімаційні відеоінструкції, які допомагають курсантам у самостійному сприйнятті навчального матеріалу, особливо під час польових занять (Похнатюк, 2019: 16).

Академія готує майбутнього командира взводу, офіцералідера, який самостійно аналізуватиме тактичну обстановку на полі бою, здобуватиме розвідувальну інформацію в умовах протидії противника, оцінюватиме обстановку та ставитиме обгрунтовані бойові завдання підлеглим, прийматиме нешаблонні рішення на бій, управлятиме штатними і доданими підрозділами.

Науково-викладацький склад НАСВ вивчив досвід війни, пов'язаний із втратами серед військовослужбовців ЗСУ від ворожих мін та вибухових предметів. Особливо непокоїла статистика щодо втрат як у живій силі, так і у військовій техніці та озброєнні серед механізованих підрозділів. Оперативно в Академії була розроблена програма курсу 3 питань розмінування та 
протидії саморобним вибуховим пристроям. Цей навчальний курс проводиться тепер для усіх фахівців, яких готує Академія. Він базується на стандартах НАТО, на базі МЦМБ створена навчальноматеріальна база для підготовки саперних підрозділів. Значну допомогу у цьому питанні надали представники збройних сил Канади, які залучаються до навчання наших інженерних підрозділів та саперів у МЦМБ, Кам'янець-Подільському Центрі розмінування. I хоча закордонні фахівці готують виключно сержантів та солдатів, викладачі НАСВ ретельно ознайомилися $з$ їхніми пропозиціями та внесли корективи у свій курс мінної безпеки, який проводять для усіх курсантів.

3 перших днів російської агресії до визволення української землі долучилися випускники Академії. Військовий виш підтримує iз ними тісні зв'язки. Робота з випускниками дозволяє усунути певні недоліки в роботі, вносити корективи у методичне супроводження занять, оперативно коригувати навчальні програми i плани.

Узагальнення бойового досвіду в зоні АТО складає основу навчального матеріалу. В Академії по-новому розглядаються проблеми щодо застосування військ, теорії та практики сучасної «гібридної війни», яка знаходиться на перетині політичної i силової складових. Вивчаються науковцями питання інформаційної війни, продовження ресурсу озброєння і військової техніки в польових умовах, удосконалення методик проведення стрільб тощо.

Велика група офіцерів Академії вивчали рівень моральнопсихологічного забезпечення (МПЗ) особового складу військових підрозділів, які брали участь в АТО. Вони виявляли військовиків, що потребували негайної психологічної допомоги або посиленої індивідуально-виховної роботи, проводили заходи зі стабілізації морально-психологічного стану окремих військовослужбовців, надавали практичну допомогу заступникам командирів по роботі 3 особовим складом щодо профілактики негативного психоемоційного стану у підлеглих. За отриманими відгуками, 3 цим відповідальним завданням вони успішно впоралися. Їхні рекомендації враховані при підготовці майбутніх офіцерів.

У 2017 р. Вчена рада Національної академії сухопутних військ на позачерговому засіданні одноголосно підтримала рішення Колегії Міністерства оборони України щодо утворення у складі видового навчального закладу - Інституту морально-психологічного 
забезпечення. Зміни структури Академії були схвалені 23 травня 2017 p. на Колегії Міністерства оборони України і затверджені Наказом Міністра оборони України від 30 травня 2017 року. Підготовка військових фахівців з МПЗ розпочалася 31 вересня 2018 року. Оперативно у НАСВ було реформовано організаційноштатну структуру, а також опрацьовані нормативні та регламентуючі документи.

Сьогодні до складу Академії входять: 3 факультети (факультет бойового застосування військ, факультет ракетних військ і артилерії, факультет підготовки спеціалістів бойового (оперативного) забезпечення), Інститут морально-психологічного забезпечення, Військовий коледж сержантського складу, Науковий центр Сухопутних військ, Навчально-науковий центр мовної підготовки, навчальні центри та військові частини забезпечення.

Курсанти НАСВ навчаються за десятьма спеціальностями. Упродовж чотирьох-п'яти років досвідчені науково-педагогічні працівники, а це не лише дві сотні докторів та кандидатів наук, але й генерали та офіцери, які безпосередньо брали участь у бойових діях та миротворчих місіях, на сучасній навчальноматеріальній базі готують майбутніх командирів для механізованих, танкових, артилерійських та ракетних підрозділів, фахівців 3 артилерійської розвідки, офіцерів-вихователів, культурологів, військових диригентів, офіцерів тактичної ланки для інженерних військ Збройних Сил та інших військових формувань України.

У НАСВ проведено успішний експеримент 3 підготовки військових фахівців на курсах Лідерства тактичного рівня з числа громадян України з вищою освітою. 3 вересня 2019 р. його поширили ще на три інших вищих військових навчальних заклади (Офіиеер України № 7-8 (78-79), 2017: 6).

В Академії постійно удосконалюється та оновлюється потужна навчально-матеріальна база. Ї̈̈ основними елементами виступають зразки найсучаснішого озброєння та військової техніки, спеціалізовані навчально-тренувальні комплекси, навчальні лабораторії, аудиторії, спеціалізовані класи, польова навчальна база. Під час навчання використовуються сучасні тренажери, на яких за допомогою комп'ютерних технологій імітується обстановка, максимально наближена до бойової. На кафедрах встановлено понад 200 одиночних та комплексних зразків тренажерного обладнання, а більше 500 зразків озброєння і військової техніки 
забезпечують якісний вишкіл курсантів у Міжнародному центрі миротворчості та безпеки. Саме в МЦМБ за останні роки відновлено та створено такі важливі елементи польової навчальноматеріальної бази, як: вогневе містечко танків та БМП, танкодром i автодром, комплекси підготовки фахівців ракетних військ i артилерії та водолазної підготовки, навчальні поля інженерної підготовки, РХБ захисту, стежки розвідника, повітрянодесантний комплекс, тактичні поля та військові містечка.

Навчально-тренувальний комплекс психологічної підготовки формує психологічну стійкість і готовність курсантів до подолання психотравмуючих чинників бою, виховує лідерські якості та вдосконалює методичні навички організації психологічної підготовки. Цей комплекс не лише отримав високу оцінку вищого керівництва оборонного відомства, але й визнано таким, який потрібно обов'язково впроваджувати у війська.

«Ми й надалі нарощуватимемо зусилля щодо професійного вишколу та виховання курсантів, формування в них необхідних морально-бойових і лідерських якостей, - говорить генераллейтенант Павло Ткачук. - Молоді офіцери - випускники вишу приходитимуть у війська всебічно підготовленими для виконання службових обов'язків за посадою. Їх вирізнятиме патріотизм, самовідданість, мужність і стійкість, безкомпромісність стосовно ворога i бажання битися за щонайменший клаптик української землі. Саме ці якості вирізняють вихованця Національної академії сухопутних військ імені гетьмана Петра Сагайдачного!» (Міцне військо - неподільна Украӥна, 2017: 6).

Колектив Академії усвідомлює і сумлінно виконує свою високу державну місію - готувати висококваліфікованих офіцерівпатріотів, захисників рідної землі, втілюючи в життя гасло навчального закладу: «ЧЕСТЬ. УКРАЇНА. ВІДВАГА».

Завдяки наполегливій праці керівництва та працівників вишу та за результатами діяльності навчального закладу, його вагомого внеску у розвиток військової освіти і науки, забезпечення обороноздатності держави, військово-історичне значення для держави та Збройних Сил України Указом Президента України, Верховним Головнокомандувачем Збройних Сил України № 551/2015 від 21.09.2015 року ВВНЗ присвоєно статус Національного (Указ Президента України «Питання Академії сухопутних військ..., 2015). 
На жаль, під час виконання бойових завдань підрозділи Української армії та інших силових структур втрачають кращих командирів та бійців. $Є$ серед полеглих українських героїв й офіцери, які здобули військовий фах в Академії. В історію назавжди увійдуть імена та прізвища кращих випускників, які поклали своє життя в ім'я миру та спокою на нашій рідній Українській землі. які своїми героїчними вчинками врятували не одне життя бойових товаришів та зробили безцінний внесок в успіх багатьох воєнних операцій. Станом на 31 липня 2020 р. десять випускників НАСВ - учасників АТО - ООС нагороджені орденом «Золота Зірка» (із них 4 посмертно), 381 випускники нагороджені орденами та медалями (3 них 57 посмертно) (Історичний формуляр НАСВ..., 2020: 76).

Висновки. Таким чином, діяльність Академії була спрямована на: покращення змісту підготовки військових фахівців 3 урахуванням досвіду застосування ЗСУ в ООС (АТО), що сприяло підвищенню якості військової освіти. Військова агресія з боку Росії щодо України поставили перед Академією, як вищим військовим навчальним закладом, якісно нові вимоги та стратегічні завдання з питань підготовки нової генерації військових фахівців для потреб армії.

Вивчення та узагальнення бойового досвіду в ході проведення АТО ООС вплинули на якість підготовки військових фахівців за спеціальностями. У ході перебудови навчального процесу зосереджено увагу на тактиці дій військових підрозділів у складі загальновійськового угруповання 3 локалізації i нейтралізації збройних конфліктів, наданні необхідної психологічної та першої медичної допомоги під час ведення бойових дій, організації морально-психологічного забезпечення у військовому підрозділі в умовах проведення війни, інформаційній безпеці. Отже, діяльність Національної академії сухопутних військ імені гетьмана Петра Сагайдачного відіграє важливу роль у забезпеченні обороноздатності держави та набуває особливого значення під час російсько-української війни.

\section{Використані посилання}

Євсєєв I. (2019). Операція Об’єднаних сил у Донецькій та Луганській областях: передумови запровадження. Воєнно-історичний вісник. Збірник наукових пращь НУОУ. Том 32, № 2. С. 2-17. 
Інтерв’ю з генерал-лейтенантом П.П. Ткачуком: «Уроки війни: як змінюється система підготовки майбутніх офіцерів у Національній академії сухопутних військ з початком АТО» (2015). Народна армія. № 91 (5426), 11 грудня.

Історичний формуляр Національної академії сухопутних військ імені гетьмана Петра Сагайдачного. (2020). 21с.

Міцне військо - неподільна Україна. (2017). Офіцеер Украӥни. № 11-12 (82-83). C. 6 .

Офіцеер України. (2017). № 7-8 (78-79).

Похнатюк С. (2019). Саме деталі бойових епізодів складають сумарну цінність бойового досвіду підрозділів ЗС України. Офічер Украӥни. № 13-14 (109-110). С. 16.

Про рішення Ради національної безпеки та оборони України від 13 квітня 2014 року «Про невідкладні заходи щодо подолання терористичної загрози і збереження територіальної цілісності України»: Указ Президента України від 14.04.2014 № 405/2014. (2014). Офіиійний вісник Президента Украӥни. № 14. C. 745 .

Ткачук П., Красюк О. (2015). Нариси історї Академії сухопутних військ імені гетьмана Петра Сагайдачного: монографія. Львів: АСВ. 124 с.

Указ Президента України «Питання Академії сухопутних військ імені гетьмана Петра Сагайдачного» № 551/2015 від 21.09.2015 року. Доступно: https://www.president.gov.ua/documents/5512015-19439. [Дата звернення 21 серпня 2020].

\section{References}

On the decision of the National Security and Defense Council of Ukraine of April 13, 2014 "On urgent measures to overcome the terrorist threat and preserve the territorial integrity of Ukraine": Decree of the President of Ukraine of 14.04.2014 № 405/2014. (2014) Official Gazette of the President of Ukraine. № 14. p. 745.

Evseev I. Joint Forces Operation in Donetsk and Luhansk Oblasts: Preconditions for Implementation. Military History Bulletin. Collection of scientific works of NUDU, Vol. 32, № 2 (2019), pp. 2-17.

Tkachuk P., Krasyuk O. (2015), Essays on the history of the Academy of Land Forces named after Hetman Peter Sagaidachny. Lviv: NAA, 124 p.

Interview with Lieutenant General PP Tkachuk: "Lessons of war: how the system of training future officers in the National Academy of Land Forces is changing with the beginning of the ATO". (2015). People's Army. № 91 (5426), December 11.

Pokhnatiuk S.. It is the details of combat episodes that make up the total value of combat experience of units of the Armed Forces of Ukraine. Officer of Ukraine, № 13-14 (109-110) 2019, p.16.

Officer of Ukraine № 7-8 (78-79), 2017.

A strong army is an indivisible Ukraine. (2017). Officer of Ukraine, № 11-12 (82-83), p. 6.

Decree of the President of Ukraine "Hetman Petro Sagaidachny Army Academy" № 551/2015 of 21.09.2015. URL: https://www.president.gov.ua/documents/551201519439.

Historical form of Hetman Petro Sagaidachny National Army Academy. Information on graduates of the Hetman Petro Sagaidachny National Army Academy, who were awarded state awards during the anti-terrorist operation as of July 31 (2020), 21 p. 


\section{Poltavets Y. \\ EXPERIENCE OF TRAINING OFFICERS IN THE CONDITIONS OF WAR IN EASTERN UKRAINE AT THE HETMAN PETRO SAHAIDACHNYI NATIONAL ARMY ACADEMY}

This article examines the experience of training officers at the Hetman Petro Sagaidachny National Army Academy during the aggression of the Russian Federation against Ukraine (2014 - 2018). It is noted that 2014 was the most difficult year for the Ukrainian army, but it was then that a mechanism of radical changes was launched to reform and strengthen it. A significant contribution to the training of the officer corps of the Land Forces is made by the leading military university of Ukraine - National Army Academy. Experience of training cadets of this. Higher military educational institution during the years of anti-terrorist operation and Joint Forces Operation. Generalization of combat experience in the anti-terrorist operation zone is the basis of educational material. The Academy is considering new issues related to the use of troops, theory and practice of modern hybrid warfare, which is at the intersection of political and force components. Scientists study issues of information warfare, extension of the resource of armaments and military equipment in the field, improvement of shooting techniques, etc.

Keywords: Hetman Petro Sahaidachnyi National Army Academy, Armed Forces of Ukraine, ATO, Joint Forces Operation, Cadet. 